\title{
The efficacy of total enteral nutrition in inducing remission and improving nutritional status in children with moderate to severe Crohn's disease
}

\author{
Ocena skuteczności terapii żywieniowej w indukcji remisji i poprawie stanu \\ odżywienia u dzieci z aktywną chorobą Leśniowskiego-Crohna
}

\author{
Jarosław Kierkuś, Sylwia Szymańska, Michał Szczepański, Anna Wiernicka, Edyta Szymańska, \\ Małgorzata Matuszczyk, Józef Ryżko
}

Department of Gastroenterology, Hepatology and Immunology, The Children Memorial Health Institute, Warsaw, Poland

Prz Gastroenterol 2013; 8 (1): 57-61

DOI: $10.5114 /$ pg.2013.34184

Key words: children, inflammatory bowel disease, nutrition, steroids.

Słowa kluczowe: dzieci, nieswoiste zapalenie jelit, żywienie, steroidy.

Address for correspondence: Prof. Jarosław Kierkuś MD, PhD, Department of Gastroenterology, Hepatology and Immunology, The Children's Memorial Health Institute, 20 Al. Dzieci Polskich, 04-730 Warsaw, Poland, phone/fax: +48 2281573 92, e-mail: j.kierkus@czd.pl

\begin{abstract}
Introduction: Growth retardation and malnutrition are very common complications of Crohn's disease in children. Tota enteral nutrition (TEN) may be considered as therapeutic approach in active disease.

Aim: To assess the efficacy of enteral nutrition in inducing remission in children with active Crohn's disease and compare it with conventional steroid therapy.

Material and methods: The study group consisted of 20 children with active Crohn's disease. All patients were placed on a total enteral nutrition regimen in hospital which was continued for 6 weeks at home. Children were examined at the time of recruitment and after 2 weeks of TEN. Those who reached remission $(n=8)$ were followed up for the next 12 months. Clinical condition expressed by PCDAl, blood tests and nutritional status were analyzed. The control group consisted of 24 children with active Crohn's disease treated with conventional steroid therapy.

Results: Remission was achieved in $40 \%$ of patients on enteral nutrition and $45.8 \%$ on steroid therapy, respectively. In both groups duration of remission was 12 months at most. In the study group there was a significant increase in body weight, body mass index and lean body mass (LBM).

Conclusions: Enteral nutrition is an effective treatment in inducing remission in children with active and moderate Crohn's disease. It can suppress gut inflammation and improve growth. Its effectiveness is comparable to conventional steroid therapy.
\end{abstract}

\section{Streszczenie}

Wstęp: Zaburzenia wzrastania i niedożywienie są częstymi powikłaniami choroby Leśniowskiego-Crohna u dzieci. Całkowite żywienie enteralne stanowi opcję terapeutyczną w aktywnej postaci schorzenia.

Cel: Ocena skuteczności terapii żywieniowej w indukcji remisji klinicznej u dzieci z aktywną postacią choroby oraz porównanie jej z konwencjonalną steroidoterapią.

Materiał i metody: Do badania włączono 20 dzieci z aktywną postacią chorobą Leśniowskiego-Crohna. Wszyscy pacjenci otrzymali w szpitalu wyłącznie żywienie enteralne, które następnie kontynuowano $w$ domu przez 6 tygodni. Wykonano badania wyjściowe przed rozpoczęciem leczenia oraz 2 tygodnie po zakończeniu żywienia. Pacjenci, którzy uzyskali remisję choroby, byli następnie obserwowani przez 12 miesięcy w celu oceny czasu remisji choroby. Oceniano: aktywność choroby określaną w skali pediatrycznej PCDAI, parametry laboratoryjne oraz stan odżywienia. Grupę kontrolną stanowiły 24 dzieci z zaostrzeniem choroby LeśniowskiegoCrohna, które otrzymały standardowe leczenie steroidami. Wyniki: Remisję osiągnięto u 40\% pacjentów otrzymujących terapię żywieniową i 45,8\% stosujących steroidoterapię. W obu grupach czas trwania remisji nie przekraczał 12 miesięcy. W grupie badanej stwierdzono znamienny statystycznie przyrost masy ciała, wskaźnika masy ciała oraz beztłuszczowej masy ciała. Wśród parametrów laboratoryjnych obserwowano zwiększenie stężenia hemoglobiny oraz białka C-reaktywnego. Nie stwierdzono różnic w poziomie OB, płytek krwi i albumin. W grupie dzieci leczonych glikokortykosteroidami odnotowano jedynie statystyczne zmiany stężenia białka C-reaktywnego. 


\section{Introduction}

Growth retardation and malnutrition are very common problems in children with Crohn's disease (CD). A meta-analysis showed that, at diagnosis, up to $85 \%$ of paediatric patients with CD have weight loss [1] and 15$40 \%$ also present growth failure [2]. Therefore, it is very important to improve children's condition as fast as possible to avoid chronic and irreversible complications. However, there is controversy surrounding the optimal treatment to induce remission in patients with active CD. Current ECCO (European Crohn's and Colitis Organisation) recommendations indicate that enteral nutrition (EN) is the first-line treatment to induce remission $[3,4]$ because of its ability to decrease disease activity and intestinal inflammation with subsequent growth improvement. The role in the management of malnutrition and its complications is also fundamental. Some studies on patients with CD showed that EN led to endo-

Table I. Baseline characteristics of CD patients treated either with TEN or conventional steroid therapy

Tabela I. Charakterystyka grup badanych i grupy kontrolnej $w$ momencie rozpoczęcia badania (średnia \pm odchylenie standardowe, SD)

\begin{tabular}{lcc} 
Parameter & TEN & Corticosteroids \\
\hline Patients & 20 & 24 \\
\hline Sex & $M^{*}(55 \%)$ & $M^{*}(54.2 \%)$ \\
\hline Age & $13.4 \pm 5.18$ & $13.8 \pm 4.34$ \\
\hline Age of onset & $11.8 \pm 3.38$ & $11.6 \pm 3.48$ \\
\hline PCDAl & $49.0 \pm 5.90$ & $44.7 \pm 10.1$ \\
\hline Disease localisation [\%]: & & \\
\hline Small intensine & 10 & 12.50 \\
\hline Colon & 20 & 12.50 \\
\hline Small intestine + colon & 70 & 75 \\
\hline Hemoglobin $[\mathrm{g} / \mathrm{dl}]$ & $10.7 \pm 1.8$ & $10.2 \pm 2.1$ \\
\hline Platelets $\left[\times 10^{9} / \mathrm{l}\right]$ & $444 \pm 141$ & $468 \pm 156$ \\
\hline Albumin $[\mathrm{g} / \mathrm{l}]$ & $32 \pm 0.6$ & $32 \pm 0.8$ \\
\hline ESR $[\mathrm{mm} / \mathrm{h}]$ & $48 \pm 5.3$ & $43 \pm 6.4$ \\
\hline CRP $[\mathrm{mg} / \mathrm{l}]$ & $6.91 \pm 8.99$ & $6.63 \pm 4.99$ \\
\hline$M-$ male & &
\end{tabular}

Wnioski: Całkowite żywienie enteralne jest skuteczne w uzyskaniu indukcji remisji u dzieci ze średnio ciężką i ciężką postacią choroby Leśniowskiego-Crohna. Ponadto poprawia stan odżywienia i hamuje zapalenie jelit. Wyniki indukcji remisji u pacjentów leczonych całkowitym żywieniem enteralnym są zbliżone do wyników indukcji remisji w porównywalnej grupie dzieci leczonych glikokortykosteroidami.

scopic healing, decreased mucosal cytokine production, and improved quality of life [5-7]. On the other hand, the pooled results of seven studies (five randomized controlled trials, one semi-randomized and one non-randomized trial) showed that there is no difference in the efficacy of EN and corticosteroids in children with acute CD. Still, chronic steroid therapy results in many long-lasting side effects, which potentially makes EN a better choice for first-line therapy in those patients. Yet, previous studies had a lot of limitations such as lack of methodological assessment of included trials or too small a number of patients to detect a significant difference in the effect of the treatment [8] and there is still uncertainty regarding the use of EN for inducing remission in CD patients.

\section{Aim}

This study aimed to assess the efficacy of 6 weeks of total EN (TEN) in children with moderate to severe CD and to compare it with conventional steroid therapy.

\section{Material and methods \\ Patient}

The study group consisted of 20 children, 11 male (65\%) and 9 female (35\%), with moderate to severe CD hospitalized in the Department of Gastroenterology, Hepatology and Immunology, Children's Memorial Health Institute, Warsaw, Poland. The study was conducted in the years 2007 to 2009 . The inclusion criteria were as follows: aged between 7 and 18 years, CD diagnosed according to Porto criteria and PCDAI (Pediatric Crohn's Disease Activity Index) score > 30. Surgical treatment in the past, and either steroid or biological (infliximab, adalimumab) therapy 1 month before recruitment were regarded as exclusion criteria. Written informed consent was obtained from parents or children's legal guardians before the study commencement.

The control group (CG) consisted of 24 children with active CD (PCDAl score > 30) treated with conventional steroid therapy. Patients treated with drugs other than corticosteroids and those who underwent surgery were excluded from this study. Created groups did not differ with respect to disease activity, CD onset, sex, age, disease duration and localization. The characteristics of the patients are presented in Table I. 


\section{Methods}

Twenty children enrolled in the study were placed on a TEN regimen with Nutrison Standard (Nutricia) provided orally or by a nasogastric tube (depending on children's and their parents' decision) in hospital and next at home. The TEN was continued for 6 weeks, each infused 1400-2200 ml. This provided approximately $50 \mathrm{kcal} / \mathrm{kg} /$ day. Only clear water was allowed orally for this 6-week period. Each child was examined at the time of recruitment and 2 weeks after TEN introduction. Clinical condition based on PCDAI, anthropometric measurements (weight and height) together with laboratory blood tests such as full blood count and platelets, erythrocyte sedimentation rate (ESR), C-reactive protein (CRP), and serum albumin were analysed. Patients who reached remission $(n=8)$ were followed up for the next 12 months to estimate the duration of remission. A PCDAl increase in value of at least 15 points with reference to the baseline score or PCDAI > 30 was regarded as loss of remission.

Each child had body mass index (BMI) calculated according to the formula: $\mathrm{BMI}=$ (weight in kilograms)/ (height in metres) ${ }^{2}$. Lean body mass (LBM) based on skin fold measurements (biceps, triceps, subscapular and suprailiac) was analysed. Lean body mass was calculated according to the formula modified by Książyk [9].

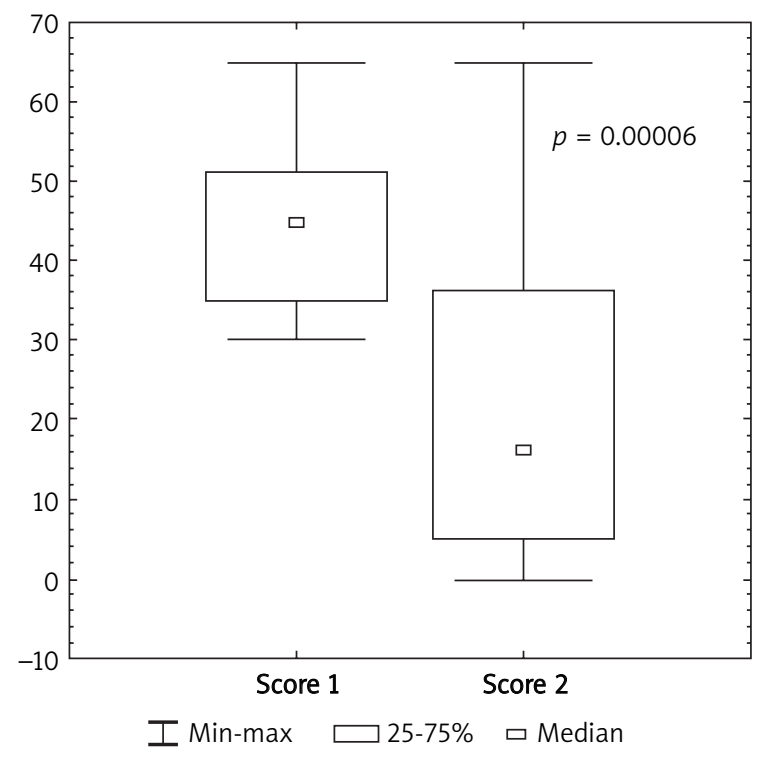

Fig. 1. PCDAl before and after treatment in patients with steroids

Ryc. 1. PCDAl przed leczeniem i po leczeniu w grupie kontrolnej (grupa KS)

\section{Statistical analysis}

The analyses were done using StatSoft Poland Software, version 5.11. To assess differences between groups (independent samples) the Mann-Whitney $U$-test was used. For the case of two related samples and repeated measurements on a single sample, the Wilcoxon test was used. Between group comparisons were made using the $\chi^{2}$ test (Fisher-Freeman-Halton). Values of $p<0.05$ were accepted as statistically significant.

\section{Results}

Twenty children were enrolled in this study. Six of them withdrew; in 4 cases it was because of treatment failure, in 2 because of patient's request. Based on intention to treat analysis, remission (PCDAI < 10) was achieved in $40 \%(8 / 20)$ of patients on TEN and $45.8 \%$ $(11 / 24)$ on steroid therapy. The remission lasted $7.75 \pm 3.2$ months in the study group and $8.5 \pm 2.48$ months in the $\mathrm{CG}$, respectively. In both groups duration of remission did not exceed 12 months. Figure 1 presents PCDAl scores before and after steroid therapy while Figure 2 shows the results before and after TEN.

A significant increase in weight, weight-for-height SDS (standard deviation score), and LBM $(p<0.05)$ was observed in TEN patients. The average changes in anthropometric parameters after 6 weeks of TEN were as follows: weight $(\mathrm{kg})+5.7$; weight-for-height SDS +0.6; LBM $(\mathrm{kg})+4.8$. For laboratory parameters there was

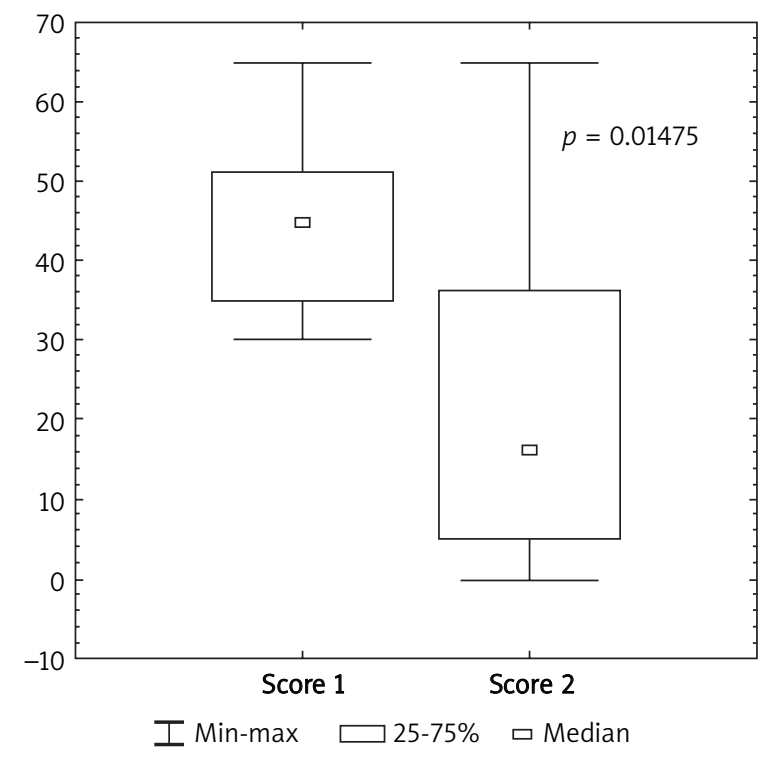

Fig. 2. PCDAl before and after TEN Ryc. 2. PCDAl przed leczeniem i po leczeniu w grupie dzieci żywionych enteralnie (grupa TEN) 
Table II. Comparison of laboratory and anthropometric parameters before and after 6 weeks of TEN therapy and conventional steroid therapy

Tabela II. Porównanie wyników wyjściowych przed leczeniem z wynikami po 6-tygodniowym leczeniu w grupie badanej (TEN) oraz grupie kontrolnej (KS)

\begin{tabular}{lcccc} 
& \multicolumn{2}{c}{ TEN } & \multicolumn{2}{c}{ Corticosteroids } \\
\cline { 2 - 5 } & Baseline & After & Baseline & After \\
\hline PCDAl & $49.0 \pm 5.9$ & $27.2 \pm 20.3^{*}$ & $44.7 \pm 10.1$ & $22.9 \pm 21.1^{*}$ \\
\hline Body mass $[\mathrm{kg}]$ & $33.2 \pm 9.1$ & $38.9 \pm 7.2^{*}$ & $39.8 \pm 8.4$ & $40.2 \pm 10.3$ \\
\hline BMI $\left[\mathrm{kg} / \mathrm{m}^{2}\right]$ & $17.9 \pm 3.35$ & $19.9 \pm 3.10^{*}$ & $17.8 \pm 3.26$ & $17.9 \pm 3.32$ \\
\hline LBM $[\mathrm{kg}]$ & $28.34 \pm 9.9$ & $33.5 \pm 7.9^{*}$ & $34.8 \pm 6.3$ & $35.4 \pm 6.8$ \\
\hline Hemoglobin $[\mathrm{g} / \mathrm{dl}]$ & $10.7 \pm 1.8$ & $11.1 \pm 2.1^{*}$ & $10.2 \pm 2.1$ & $10.0 \pm 2.7$ \\
\hline Platelets $\left(\times 10^{9} / \mathrm{l}\right)$ & $444 \pm 141$ & $426 \pm 168$ & $468 \pm 156$ & $451 \pm 141$ \\
\hline Albumin $[\mathrm{g} / \mathrm{l}]$ & $32 \pm 0.6$ & $33 \pm 0.7$ & $32 \pm 0.8$ & $32 \pm 1.1$ \\
\hline ESR $[\mathrm{mm} / \mathrm{h}]$ & $48 \pm 5.3$ & $46 \pm 7.3$ & $43 \pm 6.4$ & $42 \pm 4.4$ \\
\hline CRP $[\mathrm{mg} / \mathrm{l}]$ & $6.91 \pm 8.99$ & $4.8 \pm 5.68^{*}$ & $6.63 \pm 4.99$ & $4.87 \pm 5.1^{*}$
\end{tabular}

a significant increase in haemoglobin and erythrocytes. We also observed a significant reduction in platelets and CRP but no significant change in ESR or albumin. In the CG changes in CRP only were detected. Table II shows the exact results of laboratory and anthropometric parameters before and after 6 weeks of TEN in comparison to steroid therapy.

\section{Discussion}

First reports concerning the importance of EN in therapy of patients with acute CD were published 20 years ago [10]. Current recommendations regard EN as the first-line treatment in children with active CD [3, 4]. Such a statement is based mainly on the results of one meta-analysis [11] and open trials which revealed that EN led to endoscopic healing, decreased mucosal cytokine production, and improved quality of life of patients with CD [5-7]. The role of TEN in the management of malnutrition and its complications is also fundamental. Additionally, observations of Borrelli et al. [12] proved that the efficacy of TEN is comparable to conventional steroid therapy. In this study remission was achieved in $79 \%$ of patients with TEN and $67 \%$ with steroid therapy, but TEN seemed to be more effective as far as mucosal healing was concerned (74\% of patients on TEN vs. $33 \%$ on steroid therapy). Corticosteroids in contrast to TEN cause many long-lasting side effects, such as bone demineralization, growth failure or skin changes; therefore present ECCO statements recommend EN as a first-line therapy in children with active CD [13].

Despite all these advantages and recommendations, TEN still remains rarely introduced to patients with active $C D$, both paediatric and adults. In our study, only 14 out of 20 examined children completed the trial. This may be due to some significant limitations of nutritional therapy. The method is not very comfortable: in most cases a nasogastric tube is required, only clear water is allowed orally, and domestic life must be reorganized. Therefore, both patients and doctors often prefer oral steroid therapy to TEN.

Studies show that the most optimal period of TEN introduction is 6-8 weeks, but no clear statement has been expressed so far. There are also no guidelines on when to restart a normal diet after TEN termination. Some authors suggest introducing food slowly, especially when an elemental diet was applied, to avoid dyspeptic ailments [14]. It is also believed that the first therapy is the most effective and outweigh subsequent interventions. Some other reports reveal that TEN is more effective in children than in adults. Day et al. [15] found that TEN is the most effective in newly diagnosed CD patients (remission in $80 \%$ of newly diagnosed vs. $58 \%$ with long-lasting disease) which led to the conclusion that the earlier nutritional therapy is introduced the higher the chances of inducing remission $[7,16]$. The extent and localization of intestinal inflammation also play an important role when applying TEN. Patients with disease in the small intestine respond better to nutritional therapy than those with colonic localization [17]. In our study, however, we did not observe such a correlation.

Long-lasting remission is a primary objective of induced therapy. Previous studies revealed that remission achieved with TEN did not exceed 12 months, which was confirmed in our study. The average duration of 
remission in children on TEN was $7.75 \pm 3.2$ months and was comparable to conventional steroid therapy (8.5 \pm 2.48 months).

Improvement of nutritional status and normal physical development of children with $C D$ is another crucial target. Most reports suggest that malnutrition and growth retardation in those patients is caused by decreased protein-calorie intake [18-20]. Total EN decreases intestinal inflammation and prevents/corrects nutrient deficiencies, with subsequent growth improvement $[21,22]$. That makes TEN an effective therapy in undernourished subjects. Our study was consistent with those reports. We observed significant increase in weight, weight-for-height SDS and LBM in children placed on TEN. For laboratory parameters a significant rise in haemoglobin and erythrocytes as well as a significant reduction in platelets and CRP was detected, which proved the efficacy of such an intervention. In contrast, patients on conventional steroid courses presented changes only in CRP, which can be explained by the anti-inflammatory effect of those medications.

\section{Conclusions}

Total enteral nutrition is an effective treatment for inducing remission in children with active Crohn's disease. It can suppress gut inflammation and improve growth. Its effectiveness is comparable to conventional steroid therapy.

\section{Acknowledgments}

This study was supported by the project Grant/ Research Support from: KBN 3148/B/P01/2007/33.

\section{References}

1. Seidman E, LeLeiko N, Ament $M$, et al. Nutritional issues in pediatric inflammatory bowel disease. J Pediatr Gastroenterol Nutr 1991; 12: 424-38.

2. Newby E, Sawczenko AA, Wilson D. Interventions for growth failure in childhood Crohn's disease. Cochrane Database Syst Rev 2005; 3: CD003873

3. Travis SP, Stange EF, Lemann M, et al. European evidence based consensus on the diagnosis and management of Crohn's disease: current management. Gut 2006; 55 (Suppl. 1): i16-35.

4. Lochs $\mathrm{H}$, Dejong $\mathrm{C}$, Hammarqvist $\mathrm{F}$, et al. ESPEN guidelines on enteral nutrition: gastroenterology. Clin Nutr 2006; 25: 260-74.

5. Afzal NA, Van Der Zaag-Loonen HJ, Arnaud-Battandier F, et al. Improvement in quality of life of children with acute Crohn's disease does not parallel mucosal healing after treatment with exclusive enteral nutrition. Aliment Pharmacol Ther 2004; 20: 167-72.

6. Fell JM, Paintin M, Arnaud-Battandier F, et al. Mucosal healing and a fall in mucosal pro-inflammatory cytokine mRNA induced by a specific oral polymeric diet in paediatric Crohn's disease. Aliment Pharmacol Ther 2000; 14: 281-9.
7. Bannerjee K, Camacho-Hubner C, Babinska K, et al. Antiinflammatory and growth-stimulating effects precede nutritional restitution during enteral feeding in Crohn disease. J Pediatr Gastroenterol Nutr 2004; 38: 270-5.

8. Griffiths A. Enteral nutrition: the neglected primary therapy of active Crohn's disease. J Pediatr Gastroenterol Nutr 2000; 31: 3-5.

9. Książyk J. Body mass coefficient: a proposal of a new method of nutritional assessment. Pediatr. Pol 1995; 70; 347-51.

10. O'Moráin C, Segal AW, Levi AJ. Elemental diet as primary treatment of acute Crohn's disease: a controlled trial. Br Med J (Clin Res Ed) 1984; 288: 1859-62.

11. Heuschkel RB, Menache CC, Megerian JT, Baird AE. Enteral nutrition and corticosteroids in the treatment of acute Crohn's disease in children. J Pediatr Gastroenterol Nutr 2000; 31: 8-15.

12. Borrelli O, Cordischi L, Cirulli M, et al. Polymeric diet alone versus corticosteroids in the treatment of active pediatric Crohn's disease: a randomised controlled open-label trial. Clin Gastroenterol Hepatol 2006; 4: 744-53.

13. Caprilli R, Gassull MA, Escher JC, et al. European Crohn's and Colitis Organisation. European evidence based consensus on the diagnosis and management of Crohn's disease: special situations. Gut 2006; 55 Suppl 1: i36-58.

14. McCammon S, Beyer PL, Rhodes JB. A comparison of three defined formula diets in volunteers. Am J Clin Nutr 1997; 30: 1655-60.

15. Day AS, Whitten KE, Lemberg DA, et al. Exclusive enteral feeding as primary therapy for Crohn's disease in Australian children and adolescents: a feasible and effective approach. J Gastroenterol Hepatol 2006; 21: 1609-14.

16. Murphy MS, Johnson T, Hill S, et al. Can intensive nutritional supplementation with an elemental diet induce a true remission in Crohn's disease? J Pediatr Gastroenterol Nutr 2002; 34: 457.

17. Terrin G, Canani RB, Ambrosini A, et al. A semielemental diet (Pregomin) as primery therapy for inducting remission in children with active Crohn's disease. Ital J Pediatr 2002; 28: 401-5.

18. Motil KJ, Grand RJ, Maletskos CJ, Young VR. The effect of disease, drug and diet on whole body protein metabolism in adolescants with Crohn's disease and growth failure. J Pediatr 1982; 101: 345-51.

19. Beeken WL, Bush HJ, Sylvestert DL. Intestinal protein loss in Crohn's disease. Gastroenterology 1972; 52: 207-16.

20. Baczewska-Mazurkiewicz D, Rydzewska G. 20. Nutritional problems in inflammatory bowel disease patients. Prz Gastroenterol 2011; 6: 69-77.

21. Aiges H, Harkowitz J, Rosa J, Daum F. Home nocturnal supplemental nasogastric feedings in growth retarded adolescents with Crohn's disease. Gastroenterology 1989; 97: 905-10.

22. O'Moráin C, Segal AW, Levi AJ, Valman HB. Elemental diet in acute Crohn's disease. Arch Dis Child 1983; 53: 44-7. 